1st International Conference - Global Ethics - Key of Sustainability (GEKoS) | May 15th, 2020 | Bucharest, Romania

\title{
Stakeholder Capitalism: Progressive Dream or Nightmare?
}

\author{
Steven ROSEFIELDE \\ https://doi.org/10.18662/lumproc/gekos2020/03
}

How to cite: Rosefielde, S. (2020). Stakeholder Capitalism: Progressive Dream or Nightmare?. In A. Grigorescu \& V. Radu (vol. ed.), Lumen Proceedings: Vol. 11. 1st International Conference Global Ethics - Key of Sustainability (GEKoS) (pp. 14-23). Iasi, Romania: LUMEN Publishing House. https://doi.org/10.18662/lumproc/gekos2020/03 


\title{
Stakeholder Capitalism: Progressive Dream or Nightmare?
}

\author{
Steven ROSEFIELDE ${ }^{1}$
}

\begin{abstract}
Abstract

Joseph Stiglitr's proposes transforming America's "liberal capitalism" into "progressive capitalism" by encouraging socially responsible corporations to include progressive stakeholders in corporate decision-making. He suggests that the time may be ripe because the Business Roundtable recently endorsed efforts to make American corporations more socially responsible. He predicts that if the Business Roundtable is sincere, progressive socially responsible, stakeholder and sharebolder joint sovereign corporations will create a more dynamic economy, with greater shared prosperity and uplift the majority again to a middle-class life. However, Stiglitz fails to probe the contradictions and moral harards inherent in stakeholder-shareholder co-sovereignty that could transform his dream into a nightmare. This essay elaborates and critically evaluates Stiglitr's concept in the contemporary American political context. It shows that while progressive capitalism founded on stakeholder-shareholder co-sovereignty could have merit, corporations should reject it until Stiglitz explains how corporate boards of directors can safely test the waters.
\end{abstract}

Keywords: Joseph Stiglitz; liberal capitalism; progressive capitalism; socially responsible corporations; progressive stakeholders; stakeholder and shareholder joint sovereignty.

\footnotetext{
${ }^{1}$ University of North Carolina, Chapel Hill, USA, stevenr@unc.edu

(C) The Authors, LUMEN Conference Center \& LUMEN Proceedings.

Selection and peer-review under responsibility of the Organizing Committee of the conference
} 


\section{Introduction}

The merit of economic systems partly depends on the degree to which corporate behavior facilitates the maximization of social welfare. Socially responsible corporations support this objective; socially irresponsible ones do not. There are good and bad societies. Opinions differ widely regarding their classification. Liberals emphasize the importance of maximizing the quality of individual existence. Socialists, progressives and others stress the maximization of the quality of existence of diverse groups, or specific ideals. This essay investigates the strengths and weaknesses of Joseph Stiglitz's case for creating "progressive capitalism" built on the foundation stone of "stakeholder" corporate sovereignty.

\section{Problem Statement}

There is no body of scholarship assessing Stiglitz's case for "progressive capitalism". There is a vast literature on varieties of capitalism and capitalist corporate responsibility, progressive and socialist institutional reforms, but it bears only obliquely on Stiglitz's stakeholder corporate proposal.

Joseph Stiglitz recently sparked a revival of interest in progressive capitalism with the publication of People, Power, and Profits: Progressive Capitalism for an Age of Discontent and an article ("Is Stakeholder Capitalism Really Back?") heralding the notion that America's "Business Roundtable" may be forsaking Milton Friedman's shareholder in favor of stakeholder capitalism [1], [34], [32], [7]. He wrote that society needs a better understanding about the true source of "the wealth of a nation" which lies in the creativity and productivity of the nation's people and their productive interactions with each other and their institutions. He explains how progressive improvements of capitalism, particularly the state institutional structuring of markets [33], [35] would achieve a more dynamic economy, with greater shared prosperity and uplift the majority again to a middle-class life. He champions sustainable and inclusive economic growth [30], environmental protection and income equality [29].

\section{Research Questions/Aims of the research}

Stiglitz's outlook is consistent with a strain of American progressiveliberal academic corporate governance theory that emphasizes socially responsible democratic competitive market systems [13], and more broadly 
with the ideas of Claude Henri de Rouvroy, comte de Saint-Simon (17601825) [35], François Marie Charles Fourier (1772-1837) [11], Richard Tawney (1880-1962) [37], Oscar Lange (1904-1965)[14],and Abba Lerner (1903-1982) [16], James Meade (1907-1995) [21], and John Kenneth Galbraith (1908-2006) [12]. His appeal to progressive corporate responsibility has always been an aspect liberal competitive theory [22]. Adam Smith insisted that market competition, guided by the invisible hand was only desirable if people were attentive to their moral duty [27].

The devil however is in the details of social responsibility. Who speaks for society? Marx, Stalin, Hitler, Obama, workers, minorities, radical feminists, socialists, progressives, liberals, conservatives? state?

Is the state the voice of the people? Are corporations agents of the

Governments of all sorts assert that they are responsive to the people's will, and therefore as the people's representatives have the right to establish property right regimes, complementary law, regulate, tax, transfer and mandate. They determine stakeholders' legitimacy and power, and delegate or share this authority with private companies. Governments can impose stakeholder rights; corporations can freely embrace them, or both.

This essay deconstructs Stiglitz's case for "progressive corporate capitalism". It probes hidden assumptions using Socratic methods, and exposes the vulnerabilities of "progressive capitalism" built on stakeholder and shareholder corporate co-sovereignty.

\section{Research Methods}

This essay employs deconstruction, Socratic methods, and critical reason to assess the viability of Stiglitz's case for "progressive capitalism" built on the foundation stone of co-stakeholder and shareholder corporate sovereignty.

\section{Findings}

\subsection{Stakeholder Corporations}

Stiglitz, in the progressive-liberal rational choice tradition seeing "transparency" as the antidote for the danger of "state capture" [33], focuses on corporate rather than political governance, trying to persuade boards of directors to invest in human capital (shareholder and stakeholder capital alike) rather than short-term shareholder profit maximization which he ascribes to Milton Friedman. He admonishes capitalist (for-profit, market 
competitive) corporations to do right for everyone by doing right for shareholders and society. This win-win outlook works, if stakeholders play by Stiglitz's imperfectly competitive progressive-liberal Paretian rules [9]; that is, everyone earns his or her "fair" marginal value product [24], given a consensus Bergsonian social welfare function [4], [5], [6].

Progressive-liberal rational choice theory teaches that corporations and governments should roughly behave as Stiglitz urges subject to his "fairness" constraint [23]. Stakeholder corporations should reflect on his progressive ethical guidance, and if they concur, profit maximize accordingly.

Why then does Stiglitz contend that progressive-liberal stakeholder capitalism is a burning issue? The invisible hand and moral duty should have transformed theory into "fair" practice. Is it because corporate shareholders and corporate boards of directors disagree with Stiglitz notion of progressive duty that implicitly make stakeholders the dominant voice in "stakeholder capitalism"? [28] Do they object to his progressive-liberal Pareto rational axioms that shunt stakeholder power seeking, and moral hazard into the background [26], ${ }^{2}$ or both?

Shareholders and corporate boards of directors appear to disagree with Stiglitz's notion of progressive duty. The spirit of the "Business Roundtable" endorsement of "stakeholder capitalism" that Stiglitz references does not put stakeholders in command as he desires. It is discordant with the progressive-liberal causes that he advocates, as well as the more radical demands of other stakeholder enthusiasts. The Business Roundtable statement, echoing prior declarations of purpose, ${ }^{3}$ expresses its

\footnotetext{
2 The radical left argues that progressiveness and capitalism cannot coexist.

3 Quinn Mills reports that in the decades before 1980, in the context of a strong labor movement, American business slowly drifted toward a stakeholder model. By the mid1970s the Business Roundtable issued a pamphlet detailing what stakeholder governance meant. At that time Reginald Jones, CEO of General Electric, was the semi-official spokesman for big business. He was a strongly religious person who believed that the role of a CEO was to be the steward of the assets given to his charge. His view was that the CEO was responsible to all stakeholders, and that investors (Wall Street) were one of those shareholders and were entitled to a fair return on their investment, nothing more (these were the words of the Statement of the Business Roundtable). It was the CEOs responsibility to balance the contending interests of stakeholders. In this way, the CEO was superior to the board of directors, which represented only the shareholders. Legal niceties aside, the CEO was de facto like a monarch, with all the actual responsibility and power of the organization - he negotiated contracts with the unions, spoke for the company to the government, chaired the board of directors, etc. It was the CEO's responsibility to implement stakeholder governance.
}

Wall Street never liked this and never endorsed stakeholder governance.

In 1980 Reginald Jones retired, handing GE over to Jack Welch, a very different personality. 
members desire to be good corporate citizens and neighbors, committing them to do right by their customers, suppliers, employees, and the communities where they work. It pledges members to training and education that help develop new skills for a rapidly changing world, as well as fostering diversity and inclusion, dignity and respect. It embraces "fair" compensation, honest business practices, transparency and effective engagement with shareholders. There is no mention of employee inclusion on management boards (German "codetermination) [20], Yugoslav style worker participation [10], or Japanese consensus building worker-management practices [2]. There is no commitment to stakeholder consultation regarding entitlement, affirmative action, restorative justice, radical feminist, minority, sexuality, immigrant, transnational, global redistributionist and environmentalist causes. There is no discussion of stakeholder claims on corporate revenues, assets, product assortment, characteristics, workplace health and safety and projects. American progressives of various persuasions, including Stiglitz in his role as public intellectual urge Washington to adopt an expansive political economic agenda for the downtrodden, abused and needy [8], but the Business Roundtable is silent on all these matters.

Shareholders also appear to disagree with Stiglitz's progressive-liberal rationality axioms that require them to shun rent seeking and disregard the perils of stakeholder moral hazard. The Business Roundtable shows no indication that its members' desire restricting executive pay and perks to Stiglitz's fair compensation standard, or that members are willing to accept

Welch scrapped corporate social responsibility and stakeholder governance. The Business Roundtable Statement was quietly withdrawn and within a few months, no copies could be found. Welch ridiculed stewardship and instead, working with Wall Street and some academics adopted the shareholder dominance theory of corporate governance. The purpose of business was decreed to be to maximize financial returns for investors, who were represented by Wall Street firms. This theory was given substance by stock options which tied the incentives of corporate executives to Wall Street. A top executive of GE said in the 1980s, "I hate what I have to do to our workers [out-sourcing, wages cuts, etc.), but keep those stock options coming! "The CEO became solely responsible to shareholders. The compensation of corporate executives began the inflation of executive pay that continues to this day. Money pouring into corporate executives' pockets and into Wall Street cemented the new philosophy of corporate governance and has taken it to today. Today under increasing political and social pressure business is again giving lip-service to stakeholder governance while not changing at all the financial compensation model and the close link to Wall Street that are the essence of the shareholder dominance approach.

These issues are far more important to American politics than philosophies of conservatism or liberalism, and explain why corporate executives can be Democrats as well as Republicans. Neither political party seriously threatens the wealth making model (shareholder dominance) which has driven the increasing inequality in the American income and wealth distributions. 
the justice of stakeholders' claims for sharing wealth, income and control, including worker co-sovereignty [38]. Accepting outside stakeholders' assurances that their demands are just and they are acting in good faith could easily lead to internecine power struggles that paralyze shareholder governance and destroy corporations. Outsiders have nothing to lose. Insiders risk everything by incautiously accepting the moral hazard that comes with stakeholders' rights to co-govern, or dominate as the term "stakeholder capitalism" implies.

The radical-progressive threat to shareholder sovereignty is apparent in its contemporary American political agenda. Radical-progressives, unlike traditional progressive-liberal welfare state advocates, vigorously attack the classical principle that individuals receive the value of their marginal products or a "fair" approximation, that people should be self-reliant, that markets should distribute goods, that financial responsibility is essential, and that economic growth and prosperity are fundamental to the quality of social existence [25]. Stiglitz as a progressive-liberal stresses the importance of economic growth, development and prudent debt management. Most of today's American radical-progressives, echoing Karl Marx's Economic and Philosophical Manuscripts of 1844 [19], want a guaranteed high standard of living for everyone regardless of employment, ability and effort [3], [18], [17]. They want a completely egalitarian distribution of income and wealth, except for supplementary transfers to those with special needs, and those deserving restorative justice reparations. The especially needy include the mentally, psychologically and physically handicapped, radical feminists, ethnic and racial minorities, Moslems, immigrants, and radical-progressive activists at home and across the globe. Radical-progressives pay no heed to financial prudence in accordance with the "new monetary theory" that sees no harm from printing money without limit to pay all current expenditures and debts[39]. ${ }^{4}$ This "infantile leftism" is a replay of Nikolai Bukharin and Evgeny Preobrazhensky's ABC's of Communism (1920), instrumental in the Bolshevik economic collapse during the period of "War Communism" [15].

Business Roundtable members for obvious reasons are reluctant to adopt Stiglitz's progressive-liberalism and of course rightly fear that radicalprogressives will transform shareholder corporations into stakeholder communes for the "deserving" subsidized by Washington's money printing press that confiscate shareholders' revenue and wealth. They are unlikely to

\footnotetext{
${ }^{4}$ Modern Monetary Theory (MMT) is a school of thought whose ideology often differs from mainstream economics. MMT posits that countries with fiat currency can never really become insolvent because if they experience a financial deficit, they can always print more money.
} 
acquiesce to progressive-liberal or radical-progressive efforts at persuasion, but a radical-progressive state might compel them to do so. Should this occur, everyone will suffer except social progressives benefiting from income and asset transfers. Stakeholder capitalism at the corporate level may appear attractive to some progressive-liberal competitive market theorists when imagined in terms of abstruse social responsibility, but the danger of adverse radical progressive capture is significant.

\subsection{Sign of the Times}

America tilted toward the progressive-liberal left during the Barack Obama presidency, rejecting Stiglitz's reformist "economism" in favor of jettisoning private property, markets and Paretian rational choice whenever they impeded the immediate achievement of radical-progressive ends. ${ }^{5}$ The new radical-progressive American left demands justice now, not liberal democratic rational choice utility maximization because justice delayed is justice denied. Countervailing political forces prevented the new antineoliberal left from obtaining exclusive sovereign governing power, ${ }^{6}$ but the Obama administration energetically issued executive mandates, and administrative guidance toward this end, supported by a sympathetic judiciary and Congressional regulatory legislation. Washington has not compelled members of the Business Roundtable to appoint radicalprogressives and their constituents to their boards of directors, but the Zeitgeist is moving in this direction.

\section{Conclusions}

Joseph Stiglitz recently constructed a case for "progressive capitalism" built on the foundation stone of "stakeholder" corporate sovereignty. The notion of a socially responsible America is broadly appealing, but his proposal is flawed. Stakeholder capitalism is an oxymoron. If stakeholders are in command, the system cannot be capitalist. If capitalists are in control, stakeholders cannot be sovereign. The contradiction could be nominally reconciled by assuming that stakeholders and shareholders have identical preferences, but then stakeholder capitalism would be superfluous. The contradiction also is resolvable by assuming that shareholders and

\footnotetext{
${ }^{5}$ Economism is a term used by Vladimir Lenin to belittle the social democratic notion that capitalist markets could be reformed to better the lot of the working class.

${ }^{6}$ The term neoliberal refers to a type of "American" democratic liberalism opposed to big government and curtailed individual liberty. It is often used interchangeably with "conservative".
} 
corporate boards of directors responsibly modify their preferences to maximize the quality of social existence, but this is only possible in the never-never-land case where everyone ultimately shares identical preferences. Stakeholder capitalism built on the foundation stone of "stakeholder" corporate sovereignty is a chimera.

Stiglitz's suggestion that it is reasonable to experiment with stakeholder capitalism on a learning by doing basis is disingenuous, if as is the case there are sound grounds for concern that stakeholders will pillage assets and bankrupt their companies. The danger is apparent in American radical progressive agitation for jettisoning capitalism in a favor of an economic system that provides a guaranteed high standard of living for everyone regardless of employment, ability and effort, a completely egalitarian distribution of income and wealth, except for supplementary transfers to those with special needs, and those deserving restorative justice reparations. Stiglitz does not endorse radical progressivism. He himself favors progressive capitalism that is competitive enough to sustain efficient production, rapid economic growth and fiscal responsibility, but he needs to explain how to accomplish this in an America allergic to rational policy choice making.

\section{References}

[1] Adam I. Political Ideology Today. Manchester: Manchester University Press; 2001.

[2] Aoki M, Jackson G, Miyaiima H. Corporate Governance in Japan. London: Oxford University Press; 2008.

[3] Appiah KA. The myth of meritocracy: who really gets what they deserve? Sorting people by 'merit' will do nothing to fix inequality. Guardian; 2018 . Available from: https://www.theguardian.com/news/2018/oct/19/the-mythof-meritocracy-who-really-gets-what-they-deserve.

[4] Bergson A. A Reformulation of Certain Aspects of Welfare Economics. Quarterly Journal of Economics. 1938; 52(1): 310-334.

[5] Bergson A. Social Choice Under Representative Government. Journal of Public Economics. 1976; 6(3):171-190.

[6] Bergson A. The Concept of Social Welfare. Quarterly Journal of Economics. 1954; 68(2): 233-253.

[7] Business Roundtable. Business Roundtable Redefines the Purpose of a Corporation to Promote 'An Economy That Serves All Americans'; 2019 Available from: https://opportunity.businessroundtable.org/ ourcommitment/.

[8] Chang HJ, Stiglitz JE, The World Bank. The Rebel Within. London: Anthem; 2001. 
[9] Clark JM. Toward a Concept of Workable Competition. American Economic Review. 1940 June; 30(2):241-256.

[10] Estrin S, Uvalić M. From Illyria towards Capitalism: Did Labor-Management Theory Teach Us Anything about Yugoslavia and Transition in Its Successor States? 50th Anniversary Essay. Comparative Economic Studies. 2008; 50: 663696.

[11] Fourier C. Design for Utopia: Selected Writings. New York: Schocken; 1971.

[12] Galbraith JK. New Industrial State. New York: Houghton Mifflin; 1967.

[13] Güler A, Crowther D (editors). Handbook of Corporate Governance and Social Responsibility. London: Routledge; 2016.

[14] Lange O. On the Economic Theory of Socialism, Part One. Review of Economic Studies. 1936; 4(1): 53-71.

[15] Lenin V. Left Wing Communism. Moscow: Executive Committee of the Communist International for delegates to its $2^{\text {nd }}$ World Congress; 1920.

[16] Lerner AP. Theory and Practice in Socialist Economics. Review of Economic Studies. 1938;6(1): 71-75.

[17] Littler J. Against Meritocracy: Culture, power and myths of mobility. London: Routledge; 2017.

[18] Markovits D. The Meritocracy Trap: How America's Foundational Myth Feeds Inequality, Dismantles the Middle Class, and Devours the Elite. London: Penguin; 2019.

[19] Marx K. Economic and Philosophical Manuscripts of 1844. Moscow: Progress Publishers; 1959.

[20] McGaughey E. The Codetermination Bargains: The History of German Corporate and Labour Law. Columbia Journal of European Law. 2016; 23(1):143.

[21] Meade J. The Controlled Economy. London: Routledge; 2013.

[22] Palladino L. The Economic Argument for Stakeholder Corporations. Roosevelt Institute Working Paper; 2019. Available from: https://rooseveltinstitute.org/wp-content/uploads/2019/06/RI_EconomicArgument-for-Stakeholder-Corporations Working-Paper 201906.pdf.

[23] Pareto V. Manual of Political Economy. London: Oxford University Press; 2014.

[24] Rosefielde S. Economic Theory of the Second Worst. Higher School of Economics Journal Moscow. 2015; 19(1): 30-44.

[25] Rosefielde S. Mills Q. Populists and Progressives. Singapore: World Scientific Publishers; 2020.

[26] Sawicky M. Progressive Capitalism Is Impossible. Jacobin; 2020. Available from: https://jacobinmag.com/2020/4/progressive-capitalism-joseph-stiglitzreview.

[27] Smith A. The Theory of Moral Sentiments and Essays on Philosophical Subjects; 1759. 
[28] Stiglitz JE. A Progressive Agenda for the Twenty-First Century. In: Woolner SB, Thompson JM. Progressivism in America: Past, Present and Future. New York: Oxford University Press; 2015: 215-320.

[29] Stiglitz JE, Abernathy N, Hersh A, Holmberg S, Konczal M. Rewriting the Rules of the American Economy: An Agenda for Growth and Shared Prosperity. New York: W.W.Norton; 2015.

[30] Stiglitz JE. An Agenda for Sustainable and Inclusive Growth for Emerging Markets. Journal of Policy Modeling. 2016; 38: 693-710.

[31] Stiglitz JE. Globalization and its Discontents. New York: W.W.Norton; 2002.

[32] Stiglitz JE. Is Stakeholder Capitalism Really Back? Columbia Business School; 2019 Available from: https://www8.gsb.columbia.edu/articles/chazen-globalinsights/stakeholder-capitalism-really-back.

[33] Stiglitz JE. Markets, States and Institutions. Roosevelt Institute Working Paper; 2017. Available from: https://www8.gsb.columbia.edu/faculty/jstiglitz/sites/ jstiglitz/ files/Markets-States-and-Institutions.pdf.

[34] Stiglitz JE. People, Power, and Profits: Progressive Capitalism for an Age of Discontent. New York: W.W.Norton; 2019.

[35] Stiglitz JE. Transparency in Government. In: The World Bank. The Right to Tell. The Role of Mass Media in Economic Development. Washington DC: World Bank Institute; 2002. p. 27-44

[36] Taylor K (editor, translator). Henri de Saint Simon, 1760-1825: Selected writings on science, industry and social organization. New York: Holmes and Meier Publishers Inc.; 1975: 158-161.

[37] Tawney R. The Acquisitive Society. Republished. New York: Harcourt Brace and Howe; 2004.

[38] Weitzman M. The Share Economy: Conquering Stagflation. Cambridge MA: Harvard University Press; 1986.

[39] Wray R. Modern Money Theory: A Primer on Macroeconomics for Sovereign Monetary Systems. Houndmills, Basingstoke: Palgrave Macmillan; 2015: $137-$ $141,199-206$. 